$\psi^{\prime}(0)=A_{1} / 4 a \kappa^{2} \cdot \ln \left[R^{2} /\left\{1+\kappa^{2}\left(1-R^{2}\right)\right\}\right]$ $-B_{1} / 6 \kappa^{2} \cdot\left\{a^{3} \ln R-(3 / 2) \kappa^{2} a^{2} R^{2}+(3 / 4) \kappa^{2} a R^{4}\right.$ $\left.-\left(\kappa^{6} / 6\right) R^{6}\right\}+C_{1} \ln R+C_{2}$

$(\mathrm{A} \cdot 13)$

の両式が䆃かれる. $C_{1}, C_{2}$ 忙積分定数である.

（17）の境界条件は次のようにして得られる.

$r=0$ では $r d \psi\left(n_{d}\right) / d r=0$, また $r d \psi(0) / d r=0$. したがっ $\tau r d \psi^{\prime}(0) / d r=R \cdot d \psi^{\prime}(0) / d R=0$

(A.12) と (17) とから,

$A_{1} / 2 a \kappa^{2}-B_{1} a^{3} / 6 \kappa^{2}+C_{1}=0$

$(\mathrm{A} \cdot 14)$

$(\mathrm{A} \cdot 13)$ と $(\mathrm{A} \cdot 14)$ とから.

$\psi^{\prime}(0)=-A_{1} / 4 a \kappa^{2} \cdot \ln \left\{1+\kappa^{2}\left(1-R^{2}\right)\right\}$

$-B_{1} / 6\left\{-3 / 2 \cdot a^{2} R^{2}+3 / 4 \cdot a \kappa^{2} R^{4}-1 / 6 \cdot \kappa^{4} R^{6}\right\}+C_{2}$

境界条件 (18) により $R=1$ で $\psi^{\prime}(0)=0$ であるから， $C_{2}=B_{1} / 6 \cdot\left(-3 / 2 \cdot a^{2}+3 / 4 \cdot a \kappa^{2}-1 / 6 \cdot \kappa^{4}\right)$

これを(A-15) に入れると，

$\psi^{\prime}(0)=-A_{1} / 4 a \kappa^{2} \cdot \ln \left\{1+\kappa^{2}\left(1-R^{2}\right)\right\}+B_{1} / 6$. $\times\left\{-3 / 2 \cdot a^{2}\left(1-R^{2}\right)+3 / 4 \cdot a \kappa^{2}\left(1-R^{4}\right)-1 / 6 \cdot \kappa^{4}\left(1-R^{6}\right)\right\}$

$(\mathrm{A} \cdot 17)$
境界条件 (18) は $R=1$ 亿おける基準電位 質の浸透では不変として設けたものであるが，電解質を構成す る副イオンは対イオンに対して微量であり，また管壁より難れ て存在するととから，妥当なものであると推測する。

\section{文献}

1) F. Helfferich, "Ionenaustauscher” Bd 1. Kap. 5, 6 (1959), Verlag Chemie $\cdot G M B H \cdot W e i n h e i m /$ Bergstr.

2) H.P. Gregor, M.H. Gottlieb, J. Am. Chem. Soc. 75, 3539 (1953).

3) R. Schlög1, Z. Elektrochem. 51, 195 (1953).

4) S.A. Rice, F.E. Harris, Z. physik. Chem. (Frankfurt), 8, 207 (1956)

5) L. Lazare, B.R. Sundheim, H.P. Gregor, J.Phys. Chem. 60, 641 (1956).

6) 今井宣久, 大沢文夫, 物性論研究 46 号, 14 (1952).

7) 石橋信彦, 清山哲郎, 坂井 渡, 本誌 23,182 (1955).

8）石橋信彦，清山哲郎，坂并 渡，本誌 22，684 (1954).

9) R. Kunin, "Ion Exchange Resin" 2nd Ed. p. 46 47 (1958), John Wiley \& Sons, Inc., New York.

10) C.W. Davis, G.D. Yeoman, Trans. Faraday Soc. 49, $96 \%$ (1953).

\title{
燃料電池（IX） 高温燃料電池用マグネシアマトリックスの焼成*
}

\section{Fuel Cells (IX) The Sintering of the Magnesia Matrix} for the High Temperature Fuel Cell

\author{
高 橋 武 彦**，伊 藤 要**，鈴 木 豊** \\ Takehiko TAKAнAShI, Kaname Iтo, Yutaka SuzUKI
}

\section{1 緒言}

高温然料電池の電解質としては泿合アルカリ炭酸塩の

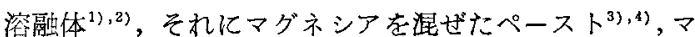
グネシアマトリックスに含浸させた溶融炭酸塩 ${ }^{1), 5) ~ 10 ~}$

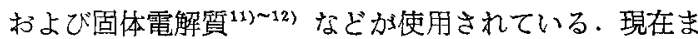
でのところ高温然料電池㹥用化の段階には達していな いが，試作電池の内で最も高電流密度を取り出し得たの は，気体然料を使用し，アルカリ若酸㫫の溶融体，また はそれをマグネシアマトリックスに含浸させたものを電 解質とした電池であろう。この種の電池は Broers らに よって始められ，最近 Kronenberg ${ }^{8)}$ および Sandler ${ }^{93}$ によってかなりすぐれたものが試作された。

著者らは嚎温然料電池を試作するに当たり，製作の签 易さ，実用化の可能性などを考虑して，マトリックス型 の電池を試作するとととした。マトリッタスの製法につ いては Broers ${ }^{53}$ の報告を除いてほとんど記述されてい ないがその材質としては混合アルカリ炭酸塭に比較的強 い酎食性を示す純マグネシアの焼結体が最も適当であろ う.したがって，著者らはまず高温然料電池のマトりッ

*昭和 38 年 3 月日本化学会第 16 年会にて一部発表

** 名古屋大学工学部芯用化学教室（愛知県名古屋市千種区不老町）
クス用としてのマグネシアの焼成条件について検討し， ナフタリンを添加し, 加圧成型後焼結する方法によって ての目的にかなった焼結体をうるてとがでさた。

\section{2 実験および結果}

\section{1 マグネシア試料}

マグネシアの試料としては試薬一級マグネシア（片山 化学製) を主として使用し，マグネシアクリンカー，お

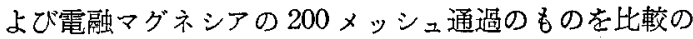
ため使用した．試薬一級のマグネシアは見掛け密度がき わめて小さく，未好理のものは $0.2 \mathrm{~g} / \mathrm{cm}^{3}$ であり.とう (敫)打密度でも $0.5 \mathrm{~g} / \mathrm{cm}^{3}$ であった．このものを焼結す ると表1の M-1〜4 K示すごとく収縮がはげしく，ク ラックも入りやすいので, 直接目的の焼結体をうること は困難であり，予備焼成をする必要があった。

著者らの予備害験によれば $1,000^{\circ} \mathrm{C}$ 前後から激しい体 積収縮が起てり，1,200 C 以上ではかなり堅く焼結し た。よって予備焼成温度を $1,200^{\circ} \mathrm{C}$ 以上とし, 主として $1,350^{\circ} \mathrm{C}$ で 10 時間予備焼成し，200メッシュ通過に粉 砕したものを使用した。また $1,200^{\circ} \mathrm{C}$ で 4 時間， 1,600 ${ }^{\circ} \mathrm{C}$ で 10 時間予備焼成した陚料当比較のために使用し t. 
マグネシアクリンカーおよよ゙電融マグネシアは市販品 を購入したもので，その予備焼成温度については詳らか でないがママグネシアァリンカーでも予備焼成温度は $1,600^{\circ} \mathrm{C}$ 以上と考沉られ，電融マグネシアはさらに高温 で処理されたものと考えられる。

\section{2 水ねり法}

まず Broers ${ }^{5)}$ の実験条件にならって試薬一級マグネ シアを $1,200^{\circ} \mathrm{C}$ で 4 時間予借愤成し，粉砕して $200 メ$ ッシュ通過のマグネシア粉末とし, それに水を加えて泥 しょうとし型に流し込んで円板状に成型, 乾燥後 1,200 , $1,250,1,300^{\circ} \mathrm{C}$ の各温度で 4 時間焼成した。 えられた ものは一応，形の整った，気孔率の比較的高いものであ ったが，その機械的强度は弱く使用中短時間内に破損し た。

マグネシア㛙結体の強度を高めるために，さらに高い 温度での焼成交試みた。すなわち $1,350^{\circ} \mathrm{C}$ で 10 時聞予 備焼成し，粉砕 (200メッシュ通過) 後，同樣にして成 型し， $1,350,1,500,1,600^{\circ} \mathrm{C}$ で 10 時間本焼成した。 得られた焼結体はかなり機械的強度の高いもので, 高温 然料電池用のマトリックスとして使用可能なものであっ た. 前報 ${ }^{13)}$ にあって 単極の分極測定用使用したマト リックスはての方法によるものであった。てれらの焼結 体試料の気孔率，機械的強度（测定法については後に述 べる）は表 1 の M-8〜10 に示すでとくであった。この 表から明らかなでとく，乙の方法ではマグネシアの焼結 体の気孔率を 35\% 以上にするとしはかなり困難であっ た.すなわち，機械的強度は焼成温度の上昇につれて大 になるが，気孔率は減少して行く、マトリックスとして 強度の点では使用可能と思われる M-8〜10 では気孔率 が 35\% 以下であった。

\section{3 ナフタリン添加, 加圧成型法} リンを空隙㓮として潦加する方法を試みたが，本実験に おいても気孔率の高いマグネシアマトリックスをうる のに，とのナフタリン添加法を応用した。すなわち，マ グネシアの粉末 (200メッシュ通過) にナフタリン紛末 (200メッシュ通過) を添加して加压成型 $\left(2 \mathrm{t} / \mathrm{cm}^{2}\right)$ し，
前報 ${ }^{14\rangle}$ において多孔性二層電極をつくる祭にナフタ

それを $1,300 \sim 1,600^{\circ} \mathrm{C}$ で焼結した．ての方法で使用し たマグネシア試料抢よび焼成条件は表 2 に示すごとくで ある、ナフタリン添加㤌気孔率を高めうるのみでなく， 加圧成型の際の成型郕としての効果もあり好都合であっ た.との方法によりえられたマグネシア焼結体は前節の 水称法によりえられたものよりも気孔率が大で，機械 的強度の高いものであった。とれらのナフタリンの添加 量および焼成条件と気孔率，収縮率および機械的強度と の関係を次行す。

2.3.1 気孔率 気孔率の測定には簡単な含水法を採 用した・すなわち、円板状の焼結体試料の見掛けの体積わ よび重量をあらかじめ测定してから水中に投入し，加熱 ふっとう 10 分後冷却して,含水のまま重量を測定し,含 水処理前後の重量の差と見掛けの体積から, 気孔の容積 百分率を計算して気孔率とした。図 1 亿気孔率の平均值 をナフタリンの添加量および加熱条件に対して示した。

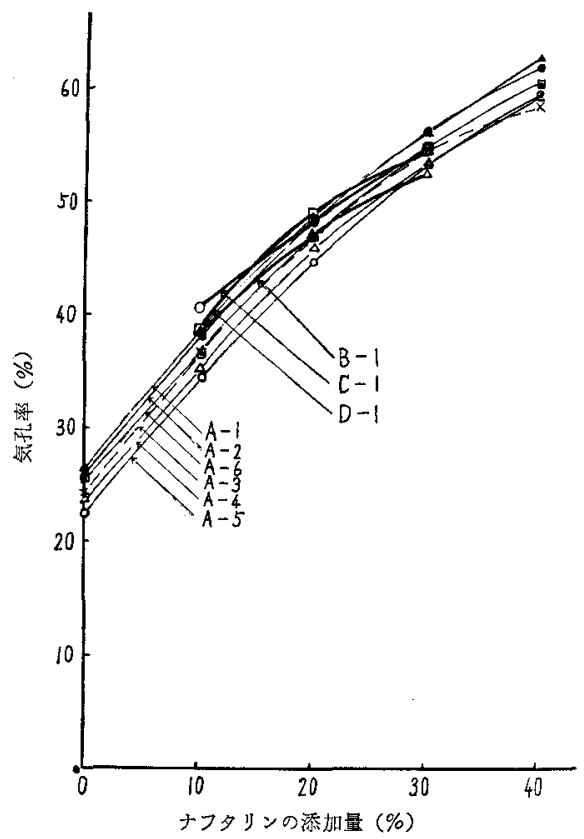

図 1 加圧成型法によるマグネシフ焼結体の気孔率 (容量 \%)

表 1 水䄈り法によるマグネシア焼結体

\begin{tabular}{|c|c|c|c|c|c|c|c|c|c|}
\hline \multirow{2}{*}{$\begin{array}{ll}\text { 実 } & \text { 験 } \\
\text { 番 号 }\end{array}$} & \multicolumn{2}{|c|}{ 予備焼成 } & \multicolumn{2}{|c|}{ 本 焼 成 } & \multirow{2}{*}{$\begin{array}{l}\text { 気 孔 率 } \\
\% \text { (容量) }\end{array}$} & \multirow{2}{*}{$\begin{array}{c}\text { 取 樎 率 } \\
(\%)\end{array}$} & \multirow{2}{*}{ 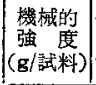 } & \multirow{2}{*}{$\begin{array}{llll}マ & ト & y & y \\
ク & ス & と & \swarrow \\
\tau & 0 & \text { 使用 }\end{array}$} & \multirow{2}{*}{ 備 } \\
\hline & ${ }^{\circ} \mathrm{C}$ & $\mathrm{hr}$ & ${ }^{\circ} \mathrm{C}$ & hr & & & & & \\
\hline M-1 & - & - & 1,000 & 2 & - & 23 & - & 不可 & こわれやナい \\
\hline $\mathrm{M}-2$ & - & - & 1,100 & 2 & 42 & 34 & - & 不可 & " \\
\hline M-3 & - & - & 1,200 & 2 & 29 & 36 & - & 不可 & かたいがラックがる \\
\hline $\mathrm{M}-4$ & - & - & 1,300 & 2 & 20 & 41 & - & 不可 & * \\
\hline M-5 & 1,200 & 4 & 1,200 & 4 & 45 & $4.7 \sim 5.4$ & 168 & 不可 & \\
\hline M-6 & 1,200 & 4 & 1,250 & 4 & - & - & 268 & 不可 & 一応の抢はできるが使用 \\
\hline $\mathrm{M}-7$ & 1,200 & 4 & 1,300 & 4 & 36 & $10.1 \sim 12.8$ & 312 & 不可 & \\
\hline M-8 & 1,350 & 10 & 1,350 & 10 & $33.5 \sim 34.5$ & $4 \sim 5$ & 524 & 可 & \\
\hline M-9 & 1,350 & 10 & 1,500 & 10 & $30.2 \sim 31.8$ & 10.5 & 718 & 可 & \\
\hline M-10 & 1,350 & 10 & 1,600 & 10 & $28.1 \sim 29.4$ & $10.8 \sim 12.2$ & 793 & 可 & \\
\hline
\end{tabular}

図中の記号洁表 2 の実験番 号に刘応するもので，マグ ネシアの試料および，焼成 条件を示している（図 3,4 の記具についても同じ).

この図から明らかなごし く，ての方法によってつく られたマトリックスの気孔 率はほとんどナフタリンの 添加量によってきまり，炇 成温度および試料の種類に 
表 2 加圧成型法におけるマダネシフ試料および㜔成条件

\begin{tabular}{|c|c|c|c|c|c|}
\hline \multirow{2}{*}{$\begin{array}{l}\text { 寒 } \\
\text { 番 }\end{array}$} & \multirow{2}{*}{ マゲネンア試料 } & \multicolumn{2}{|c|}{ 予備㨬成 } & \multicolumn{2}{|c|}{ 本焼 成 } \\
\hline & & ${ }^{\circ} \mathrm{C}$ & $\mathrm{hr}$ & ${ }^{\circ} \mathrm{C}$ & $\mathrm{hr}$ \\
\hline A-1 & $\mathrm{MgO}$ (試 薬一禹) & 1,350 & 10 & 1,300 & 4 \\
\hline$A-2$ & " & 1,350 & 10 & 1,350 & 4 \\
\hline A-3 & " & 1,350 & 10 & 1,400 & 4 \\
\hline$A-4$ & " & 1,350 & 10 & 1,500 & 4 \\
\hline A-5 & " & 1,350 & 10 & 1,600 & 4 \\
\hline$A-6$ & " & 1,350 & 10 & 1,350 & 10 \\
\hline B-1 & " & 1,600 & 10 & 1,600 & 10 \\
\hline$C-1$ & マクネンアクリンカー & - & - & 1,600 & 10 \\
\hline$D-1$ & 電融マクネンア & - & - & 1,600 & 10 \\
\hline
\end{tabular}

はあまり依存しない、すなわちナフタリンを 10〜30\% 添加することによって，約 35〜55\% の気孔率でかなり 機械的強度の高いものをうるてとができた。 $40 \%$ 源加 した場合には気孔率はさらに大きくなったが，機械的強 度が弱くなり焼きくずれを生ずる場合もあった。このよ うにして，ナフタリンの添加量を加減するととによって 25〜 55\% の間の希望の気孔率のものをうるととができ るようにはった。

2.3.2 機械的強度 セラミックスの機械的強度は一 般に引誩り，生縮，曲げ，ねじり，衝撃などについて武 驗されるが占), 著者らは高温然料電池用マトリックスと しての使用条件を考慮して，次のごとき方法によって， 非板状試料の破壊強度を測定した。

測定装置は図 2 に示すごときもので，まず所定の条件 で焼成した直定 $12 \mathrm{~mm}$ の円 板状試料をカーボランダムで 呼摩して厚さを $0.5 \mathrm{~mm}$ にそ ろえ，図 2 に示した陚料台の 上に犆き, 直径 $3 \mathrm{~mm}$ の半球 型をした加圧棒の先端を円板 試料の中心にくるように装置 した.このようにしてこの加 圧装置の荷重を図 2 に示すご とく予備荷重むよび水で次第 に増加して行き，破壊点付近 では水の流速を一定にすると とによって荷重速度を一定と し試料の破壞したときの加压 装置の全荷重をもってての試 料の機械的強度の比較值とし た・その結果は図 3 に示すこ とくなった。この図から明ら かなように，機械的强度はナ フタリンの添加量によって大 きく影響され，20\%の添加に よって無添加の場合の約半分 になった。また，マグネシア

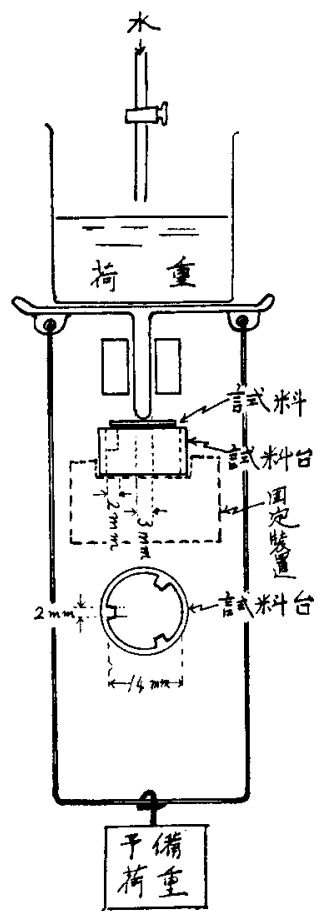

図 2 機械的強度の 測定装置

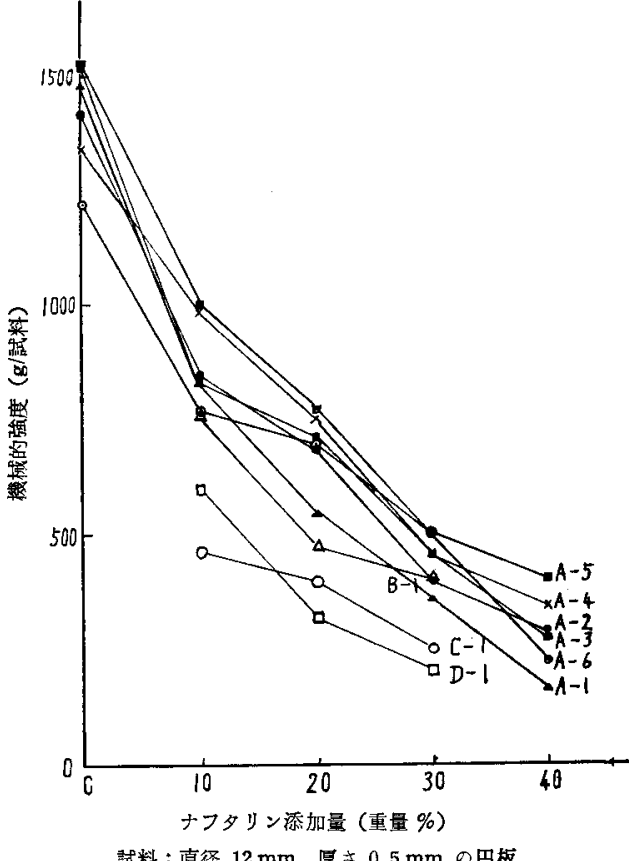

試料：直经 $12 \mathrm{~mm}$ 厚さ $0.5 \mathrm{~mm}$ の円板

図3ナフタリン添加，加圧成形法によるマク゚ネシフ 焼結体の機械的強度

試料の予備焼成温度によってもかなり異なるととがわか った。

2.3.3 収縮率 各試料の直径方向について測定した 収縮率を図 4 に示した。この結果によれば収縮率はマグ ネシアの予備㜔成温度および本焼成温度に大きく影響さ れる・ナフタリンの添加量についてみると，添加量 $30 \%$ までは收縮率は小さく，40\%になると大きな収縮率を

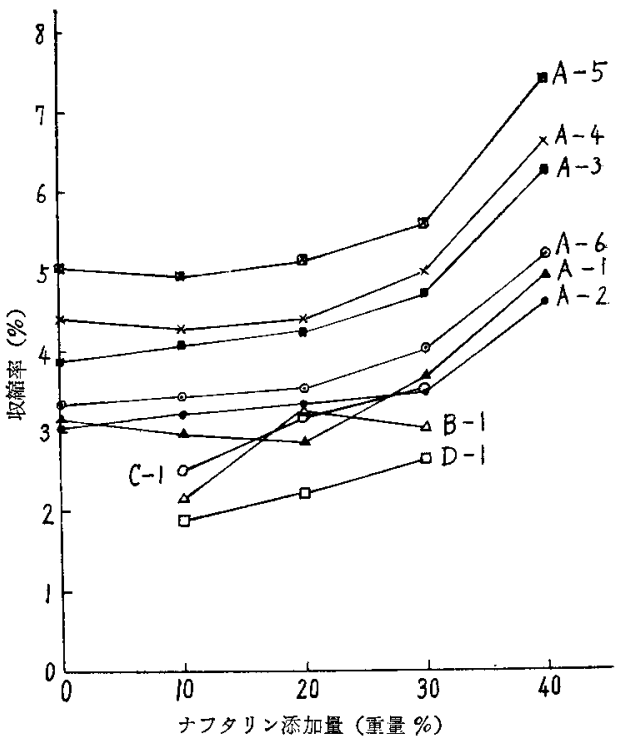

図 4 ナフタリン添加，加圧成型法によるマダネシフ 燒結体の収縮率（円板試料の直径について） 
示した.すなわち、ナフタリン添加量 $30 \%$ 以下では 2 5.5\% の収縮率で，水权り法の場合の 5 13\% 飞比 較してかなり小さいので，烧成時におけるクラックの入 る割合も少なくなった。実際にマトリックスの製造条件 として使用したナフタリン添加量 20 30\% では, 表 2 のA-2〜6 の焼成条件で 3〜5\% の収縮率であり，ほと んどクラックが認められなかった。

\section{3 考察}

\section{1 マグネシア焼結体の機械的強度と気孔率}

ナフタリンを添加する加圧成型法によってつくられた マグネシア焼結体の気孔率は図 1 から明らかなごとく， ナフタリンの添加量にほほ比例して増大する。一方図 3 によればその機械的強度はナフタリンの添加量にほぼ反 比例している.よって機械的強度之気孔率との閪にはか なりの相関関係のあるてとが推測される、したがって， 今横軸に気孔率をとり，縦軸に一定重量当たり，すなわ ちマグネシア粒子の数を一定とした状態に換算した機械 的強度を示す之図 5 のごとくなった。ままた水权り法につ いても同様济算して示した，図中の記号は表 1,2 に示 した実験番号に対応するものである。

ての図からわかるととは次の 3 つ要約できる．すな わち(1) 水和り法によるものは同一気孔率におりる加圧 成型法によるものに比単してかなり小さい機械的強度を 示す. (2) ナフタリン添加加圧成型法ではマグネシアの 同一試料 (同一予備烧成温度)のものについて，機械

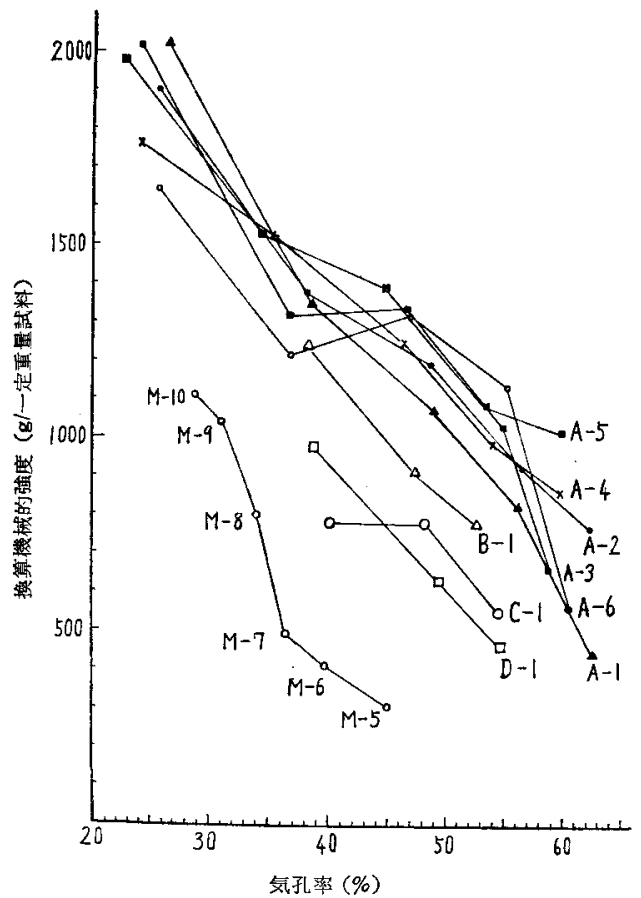

四 5 マグネシフ試粼の気孔率と換算機械的強度との䦕係
的強度が気孔率の増大につれてかなり急激に减少してい る. (3) 乙の機械的強度は同一気孔率の試料について本 焼成温度よりも予储焼成温度により大さく影響される。

これらの結果から炊のごときてとが推測される。すな わち、ナフタリンを添加して気孔率を增大する方法で は，ナフタリン無添加の際にマグネシアの粒子が当然入 るべき位置に，ナフタリン粒子が入って成形される・次 にそれを焼成することによって，そのナフタリン粒子が 型華して，その位置は空席になる。したがって，マグネ シア粒子一つ当たりのほかのマグネシア粒子の結合点は ナフタリンの添加量の增大,すなわち，気孔率の増大につ れて減少する。一方てのような焼結体の機械的強度が主 として結合点の数と結合点一つ当たりの強度に依存する ものをすれば，結合点一つ当たりの強度が同一である場 合には，気孔率の増大につれて結合点が減少するから， 当然機械的強度も減少するであろう。また結合点一つ当 たりの機械的強度はマグネシア粒子の状態，すなわち予 備焼成の条件および本焼成の条件によってきまってくる であらう。

前述の推測を検討するために，炊のでとき考察を試み た，今，一定重量の円板試料に対する強度に換算した機 械的強度を $S$, 結合点一つ当たりに相当する強度を $a$, 一定重量当たりのマグネシア粒子の数を $N$ ，マグネシ ア粒子一つ当たりの結合点の数を $n$ とし, 結合点の数と 強度が試料の機械的強度に対する支配的因子之仮定すれ ば，Sは anN の積に比例するであるう。

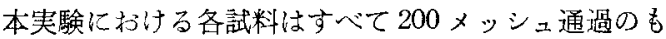

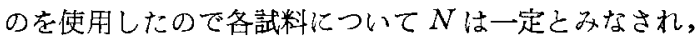
また同一マグネシア試料で烧成条件の一定のときには $a$ は一定とみなされるであうう。したがって S/n は一定 となる。

次にとの結合点の数 $n$ と気孔率との関係を求めるの 亿均一剛球の各種充てん方式仍ける接触点の数々気孔 率 (空隙率) との関係 ${ }^{16)}$ を利用した。このような模型 と本実験のマグネシア焼結体とでは粒子の配列構造に相 違があると思われるが，てのような焼結体の機峨的強度 が主として結合点の数传存するものならば，気孔率と 接触点の数すなわち結合点の数および機械的強度との間 の対応関係を見いだすととができるであろう．すなわ ち, 均一刷球の各種充てん方式での接触点の数と気孔率 は表 3 の第一項，第二項に示されている．との気孔率に 対応する各マグネシア試料の换算機械的強度を図 5 から

表3 マダネシア焼結体の結合点一つ当たりの比較強度

\begin{tabular}{|c|c|c|c|c|c|c|c|}
\hline \multirow{2}{*}{ 充てん方式 } & \multirow{2}{*}{$\begin{array}{l}\text { 接触点 } \\
\text { 数 } \\
(n)\end{array}$} & \multirow{2}{*}{$\begin{array}{c}\text { 気。孔率 } \\
(\%)\end{array}$} & \multicolumn{5}{|c|}{$\begin{array}{c}\text { 結合点一つ当たりの比較強度： } \\
S / n \times 10^{-2}(\mathrm{~g})\end{array}$} \\
\hline & & & A-1 & $A-3$ & $A-5$ & B-1 & D-1 \\
\hline 正力 & 6 & 47.64 & 1.8 & 2.1 & 1.9 & 1.5 & 1.1 \\
\hline 六方系粗充てん & 8 & 39.54 & 1.6 & 1.6 & 1.8 & 1.5 & 1.2 \\
\hline 最密充てん & 12 & 25.95 & 1.7 & 1.6 & 1.5 & - & - \\
\hline
\end{tabular}


表 4 マグネシアマトリックスの形態と機械的強度

\begin{tabular}{|c|c|c|c|c|c|c|c|c|}
\hline \multirow[b]{2}{*}{ マゲネンア試料 } & \multicolumn{2}{|c|}{ 本 烧 成 } & \multicolumn{2}{|l|}{ 試 } & \multicolumn{2}{|l|}{ の 型 } & \multirow{2}{*}{ 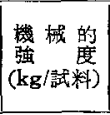 } & \multirow{2}{*}{$\frac{(\text { 両山⿴囗十板) }}{\text { (平滑可板) }}$} \\
\hline & ${ }^{\circ} \mathrm{C}$ & $\mathrm{hr}$ & 型 & 直彺 & \begin{tabular}{|l} 
作動面 \\
厚さ \\
$d(\mathrm{~mm})$ \\
\end{tabular} & $\begin{array}{l}\text { 外緑部 } \\
\text { O厚さ } \\
D \text { (mm) }\end{array}$ & & \\
\hline \multirow{2}{*}{ 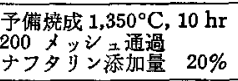 } & 1,350 & 10 & 平清队板 & 30 & 2.81 & 2.81 & 21.46 & \multirow{2}{*}{1.69} \\
\hline & 1,350 & 10 & 両凹円板 & 30 & 2.88 & 4.77 & 36.36 & \\
\hline \multirow{2}{*}{$\begin{array}{l}\text { 電髉マグネジン添加量 } \quad 20 \% \\
\text { ナフタ }\end{array}$} & 1,600 & 10 & 平滑円板 & 30 & 2.72 & 2.72 & 12.44 & \multirow{2}{*}{1.82} \\
\hline & 1,600 & 10 & 両凹円板 & 30 & 2.72 & 4.60 & 22.66 & \\
\hline
\end{tabular}

\section{4 総 括}

高温然料電池用のマグネシア マトリックスは，気孔率の大き い, 汃つ機械的強度の育い与 を必要とする。との目的にかな ったマグネシア焼結体をうる方 法として，ナフタリンを添加し
求め，その值を各気孔率に対応する接触点の数（すなわ ち, 結合点の数 $n$ 亿相当す尚)で割った值が第 4 項以 下に示されている．との值は結合点一つ当たりの比較強 度を示するので, $S / n$ に相当し，著者らの推測した機構 によれば同一試料で同一焼成条件では一定となるべきで ある. 表 3 の結果は強度測定用の試料調製における不均 一性，測定実験の精度を考慮すれば，各マグネシア試料 について，ほぼ一定值をえたものとみなしてよいであろ 亏.

これはナフタリンを添加した 加压成形法による多孔性マグネ シア焼結体の機械的強度につい て, 粒子の配列構造的因子, 形 態的因子なども当然影響するで あろうが，結合点の数之結合点 一つ当たりの強度がかなり支配 的に影響するものと考えてよい であろう。

\section{2 形態的補強}

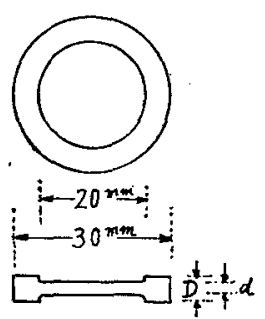

困 6 両凹円板型マグネ シアマトリックス
前述のごとき考察によれば，所定の気孔率を保って， マグネシア焼結体の機械的强度を一定限度以上にするこ とは困難である.したがって所定の気孔率を保ちつつ， 機械的強度を高めるために仕，形態的な補強を必要とす る、これにはいらいろな型が考えられようが，著者らは 図6に示すごとく，電極の作動面とならない外縁部を厚 くした両凹円板型にして補強した。このような補強をし た場合としない場合について各值径 $30 \mathrm{~mm}$ の試料をつ くり2.3.2で述べた方法と原理的に同じ方法で機械的強 度を測定した結果を表 4 亿示す．すなわちとのように外 縁部の補強をすることによって機械的強度を 1.7〜 1.8 倍にするしとがでさた。
た加圧成形法を試み，従来の水称り法によるものと比較 検討した。

（1）本法により得られたマグネシア焼結体の気孔率 注としてナフタリンの添加量に依存し, 25 55\%の範 囲で希望の気孔率のものをうることができるようになっ た.

（2）その機械的強度は，気孔率の増大につれて減少 し，また焼成条件にも依存する。乙のような烍結体の機 械的强度は主としてマグネシア粒子間の結合点の数と， 結合点一つ当たりの強度とに农存しているものと考えら れる。

(3) マトリックスの外緑部を厚くするととによっ て，大きい気孔率を保ちつつ，機械的強度を $1.7 \sim 1.8$ 倍にすることができ，高温然料電池用としてきわめてす ぐれたものをうることができた。

\section{文献 \\ (昭 39-1-13 受理)}

1) H.H. Chambers, A.D.S. Tantram, "Fuel Cells" edited by G.J. Young, p. 94 (1960), Reinhold Publ. Corp.

2) D.L. Douglas, ibid. p. 129 (1960).

3) G.H.J. Broers, M. Schenke, "Fuel Cells" vol. 2 edited by G.J. Young, p. 6 (1963), Reinhold Publ. Corp.

4) E.B. Shultz, K.S. Vorres, L.G. Marianowski, H.R. Linden, ibid. p. 24 (1963).

5) G.H.J. Broers, "High Temperature Galvanic Fuel Cells" (1958), Thesis, University of Amsterdam.

6) G.H.J. Broers, J.A.A. Kettelaar, "Fuel Cells" edited by G.J. Young, p. 78 (1960), Reinhold Publ. Corp.

7) E. Gorin, H.L. Recht, Chem. Eng. Prog. 55, 51 (1959).

8) M.L. Kronenberg, J. Electrochem. Soc. 109, 753 (1962).

9) Y.L. Sandler, ibid. 109, 1115 (1962).

10）秦卓地，村山邦彦，本誌 30，773 (1962).

11) E. Baur, H. Preis, Z. Elektrochem. 43, 727 (1937).

12) J. Weissbart, R. Ruka, J. Electrochem. Soc. 109, 723 (1962).

13) 伊藤 要, 高檑武彦, 本誌 31，766 (1963).

14）高橋武彦, 伊藤 要, 川合 治, 鈴太 䇺, 本誌 30，38 (1962).

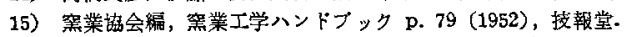

16）久保牌一郎, 水渡英二, 中川有三，早川宗八郎，“粉体・理論と 応用” p 210 (1962)，丸善. 